\title{
The Impact of Biotic and Abiotic Stress Factors on Development of European Ash Tissue Cultures
}

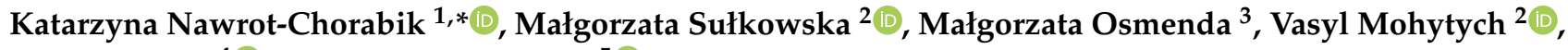 \\ Ewa Surówka ${ }^{4}$ [D and Dariusz Latowski ${ }^{5}$
}

check for

updates

Citation: Nawrot-Chorabik, K.;

Sułkowska, M.; Osmenda, M.;

Mohytych, V.; Surówka, E.; Latowski,

D. The Impact of Biotic and Abiotic

Stress Factors on Development of

European Ash Tissue Cultures.

Forests 2022, 13, 59. https://doi.org/

$10.3390 /$ f13010059

Academic Editors: Teresa Lino-Neto and Paula Baptista

Received: 2 December 2021

Accepted: 31 December 2021

Published: 4 January 2022

Publisher's Note: MDPI stays neutral with regard to jurisdictional claims in published maps and institutional affiliations.

Copyright: (c) 2022 by the authors. Licensee MDPI, Basel, Switzerland. This article is an open access article distributed under the terms and conditions of the Creative Commons Attribution (CC BY) license (https:// creativecommons.org/licenses/by/ $4.0 /)$.
1 Department of Forest Ecosystems Protection, Faculty of Forestry, University of Agriculture in Krakow, 29-Listopada Ave. 46, 31-425 Krakow, Poland

2 Forest Research Institute, Braci Leśnej 3, Sękocin Stary, 05-090 Raszyn, Poland; m.sulkowska@ibles.waw.pl (M.S.); v.mohytych@ibles.waw.pl (V.M.)

3 Olkusz Forest District, The State Forests National Forest Holding, 32-300 Olkusz, Poland; malgorzata.osmenda@katowice.lasy.gov.pl

4 The Franciszek Górski Institute of Plant Physiology of the Polish Academy of Sciences, ul. Niezapominajek 21, 30-239 Kraków, Poland; e.surowka@ifr-pan.edu.pl

5 Faculty of Biochemistry, Biophysics and Biotechnology of the Jagiellonian University, Gronostajowa 7 Street, 30-387 Kraków, Poland; dariusz.latowski@uj.edu.pl

* Correspondence: rlnawrot@cyf-kr.edu.pl

\begin{abstract}
Fraxinus excelsior L. is threatened by a variety of environmental factors causing a decline of the species. The most important biotic factors negatively affecting the condition of the F. excelsior population are fungi such as the pathogen Hymenoscyphus fraxineus. Abiotic factors with potentially harmful effect to the F. excelsior population are the accumulation of heavy metals and salinity in soils. Thus, the aim of this study was to investigate the impact of selected biotic and abiotic stress factors to determine which of them pose a threat to European ash. The study was conducted using in vitro techniques based on callus and seedlings regenerated via indirect organogenesis. Tissue cultures exclude the influence of other factors, including the environmental impact on ash extinction. The results confirmed very strong pathogenic potential of $H$. fraxineus in which after 14 days the callus tissue cells died as the tissue failed to activate its defense mechanisms. Experiments showed the high toxicity of cadmium in concentration of $0.027 \mathrm{mmol} / \mathrm{L}$. Salinity caused the activity of oxidation enzymes to vary among seedlings and calluses in the control suggesting the enzymes play a role in controlling the morphogenetic development of tissue cultures.
\end{abstract}

Keywords: European ash; indirect organogenesis; ash dieback; catalase; peroxidase; chlorophyll fluorescence

\section{Introduction}

European ash (Fraxinus excelsior L.) is a very valuable element of nature [1,2]. In forestry, the species is particularly valued for its fast growth [3] and high quality hard wood [4]. It is also frequently planted in urban greenery due to its high aesthetic values. European ash leaves and bark, on the other hand, are used in anti-inflammatory and anti-rheumatic herbal preparations [5]. Alas, the F. excelsior occurrence throughout its natural range declines, which causes extensive ecological damage to the biodiversity of forest ecosystems and significant economic loses in forestry and the wood industry [6]. The ash tree's decline and high mortality is due to its high vulnerability to biotic and abiotic stressors [3], both the intensity and interactive effects of which are modified by omnipresent global climate change [7].

The most important biotic factors posing a threat to F. excelsior include fungi. Recently, the biggest threat to F. excelsior in Europe has been Hymenoscyphus fraxineus (T. Kowalski), an ascomycetous fungus [8,9] from Asia [10]. H. fraxineus is a very contagious invasive species in Europe, that appeared on the continent with seedlings of Manchurian ash (Fraxinus 
mandshurica Rupr.). Based on genome association studies F. excelsior, the European ash is found to be particularly susceptible to infection by $H$. fraxineus [11]. The important characteristic of this pathogen is that it is able to infect ash seeds, seedlings, as well as older trees regardless of their biosocial position and habitat properties. The $H$. fraxineus related disease is called ash dieback. The disease was observed for the first time in Poland in the early 1990s, and since then it has spread throughout Europe. The characteristic symptoms of the disease include wilting of leaves, extensive necroses on shoots and branches and gradual crown thinning and dieback. Due to the high infectious potential of $H$. fraxineus and the general strategy of limiting the spread of infectious diseases adopted by State Forests (a state-owned forestry holding, administrating the vast majority of Polish forests), European ash ceased to be used in forest renewals in Poland. The disease which is ash dieback is caused by $H$. fraxineus has been included in the European and Mediterranean Plant Protection Organization (EPPO) alert list containing the most important pests and pathogens threatening economically important plant species, including trees $[2,9,10,12-19]$. Two additional fungi, that is, Minimidochium sp. and Thielavia basicola, belong to the most commonly occurring endophytes of European ash [20]. Under normal conditions their colonization of ash tissues, predominantly leaves, is completely asymptomatic causing no harm to the host tree [21]. However, when the plant is under the influence of stress caused, among other things, by toxic substances accumulated in the soil e.g., compounds of heavy metals, the plant's immunity deteriorates significantly, as a result of which endophytes become more aggressive, which further worsens the health of the host plant. On the basis of the presented information, it is advisable to establish whether endophytes may be pathogenic. Therefore, it is desirable to conduct research that determines the pathogenic potential of fungi. The pathogenic potential of a particular fungus against a given plant species must be evaluated on a case-by-case basis. This can be accomplished relatively rapidly and easily with the use of a dual culture method involving co-culturing of fungi and in vitro grown callus or in vitro regenerated seedlings of a given plant. The research carried out with the use of dual cultures shows that the endophytic growth is usually retarded or completely stopped before reaching the plant co-partner whereas fungal pathogens in such a setting, e.g., those of the genus Heterobasidion, usually entirely overgrow the plant tissues relatively fast [22]. The observed different degree of colonization of tissue cultures by fungi is due to the fact that plant tissues cultured in vitro release numerous secondary metabolites to the medium with various levels of antifungal activity. Under normal conditions, such a barrier is sufficient to interrupt the mycelial growth of endophytes or other saprotrophic fungi, but pathogens are able to overcome this defense and to kill the cultured tissues [23,24].

Apart from fungal pathogens, a number of abiotic factors may negatively affect the health condition of plants, the most important of which are drought (a factor not the subject of research in this manuscript), heavy metal pollution and high salinity of soils. An example is the research carried out on the species Prunus sargentii (Rehder) H.Ohba (1992) and Larix kaempferi (Lamb.) Carr., which showed that woody plants, as a result of drought show visible reduction in leaf size, diminution of photosynthetic activity of the water potential in the assimilation material, and a reduction in sap movement as a result of damage to the plant's xylem. These changes contribute to irreversible alterations in the plant phenotype and physiology, and eventually to plant death [25]. In addition, due to human activity, especially in many economic sectors such as agriculture or heavy industry leads to the formation of dust and gases containing heavy metals particularly harmful to plants [26]. The accumulation and occurrence of heavy metal free ions in the forest soil is a significant factor negatively affecting the growth conditions of forest trees [27]. Long-term observations indicate that the most dangerous elements are nickel, cadmium and lead. The interaction between these elements and plants causes the appearance of many undesirable effects. It has been proven that the excess of nickel concentrations negatively affects the plants' overall development, resulting in chloroses and necroses of tissues $[28,29]$. In contrast, cadmium interferes with the uptake of minerals by plants [30]. 
Lead adversely affects the development of a plant root systems as well as the growth and development of other plant organs [31]. These unfavorable effects of heavy metals on living organisms and the environment have influenced the application environmental pollutants determination for use in biomonitoring. F. excelsior, as a species susceptible to the adverse effects of heavy metals, is an excellent biomonitor of the environment. These studies on the accumulation of heavy metals in plant tissues of F. excelsior are used to determine the actual degree of environmental pollution in regions with common ash. On this basis, the extent of damage to the plant cells caused by heavy metals can be determined [32]. Laboratory tests conducted at cellular level of heavy metals, lead in particular, cause build-up of cell wall deposits and disruption of the organelles including thylakoid grana, which damages the metabolism of photosynthesis [33]. Build-up of lead in the nucleolus and in mitochondria massively disrupts the structure and physiology of cells leading to their death. For this reason, plants have developed some methods to recognize heavy metals in their cells. The detection of heavy metals triggers defense mechanisms in plant tissues including production of chelator secondary metabolites. The same reaction occurs in plant callus cultures in vitro [34]. Through these mechanisms a certain level of heavy metal tolerance may be maintained by plant tissues. Another harmful abiotic factor discussed in this work is the salinity of the substrate. Similar to heavy metal pollution, the salinity of soils in many regions of the world has increased due to human activity and global warming. Estimates show that by 2050 the area of high salinity soils (>2000 ppm) will increase by 14\% [7,35]. According to the Food and Agriculture Organization of the United Nations (FAO) (2010) the process of salinization and sodification of soils, which is a multi-factorial phenomenon, may occur both naturally, e.g., as a result of rising sea levels or intrusion of water from the sea, rivers or groundwater, but also be of anthropogenic origin associated, for example, with intensification of agriculture or excessive use of mineral fertilisers. It is estimated that over 1100 million ha of soils on all continents are currently affected by salinity and sodicity, of which $60 \%$ are saline soils, $26 \%$ sodic soils, and $14 \%$ sodic-saline soils. For example, Europe introduces about 1 million tonnes of salt into the environment each year, and the United States up to about 10 times more salt per year on paved surfaces, resulting in secondary salinisation. Climate change can exacerbate the salinization/sodification of soils and lead to rapid inhibition of individual plant species, as well as entire habitats. Therefore, a comprehensive understanding of how individual plants respond to salinity stress is essential to improve the salt tolerance of (crop/industrial) plants, consequently improving agricultural production, the provision of essential ecosystem services, and the achievement of the Sustainable Development Goals. Soil salinity disrupts ion homeostasis, and causes osmotic and oxidative stress (the excess of reactive oxygen species), thus affecting numerous physiological processes in the plant tissues [36,37]. Keeping in view the negative impact of soil salinity on plant growth and development, it is essential to identify the genetic variation and genes responsible for resistance to salinity stress in plants [38]. Reactive oxygen species (ROS) such as singlet oxygen $\left({ }^{1} \mathrm{O}_{2}\right)$, superoxide anion $\left(\mathrm{O}_{2^{-}}\right)$hydroxyl radical (HO•) and hydrogen peroxide $\left(\mathrm{H}_{2} \mathrm{O}_{2}\right)$ originate mostly as byproducts of oxygen metabolism, as well as in other enzymatic reactions [36,39]. The excess $\mathrm{H}_{2} \mathrm{O}_{2}$ or other ROS species resulting from its decay is by itself dangerous for various cell components, making efficient ROS reduction an essential process ensuring the integrity of cell structures and effective regulation of metabolic processes [36,37,39-42]. Activity of some antioxidant enzymes, such as catalases CAT or peroxidases POX, through regulation of $\mathrm{H}_{2} \mathrm{O}_{2}$ content influence various physiological processes [36,37,39], including e.g., rhizogenesis in Mesembryanthemum crystallinum L. [43,44], or organogenesis in Acanthophyllum sordidum (Bunge ex Boiss) [45] or Crocus sativus L. [46] in in vitro cultures. The increased level of ROS generated via the transfer of excess electrons to oxygen under environmental stress conditions lead to a decline in photosynthetic efficiency, and can damage photosynthetic apparatus leading to inhibition of carbon assimilation and finally reduced plants growth.

Another parameter that can be used to monitor the condition of plants or plant tissues in vitro is chlorophyll fluorescence measured as the maximum quantum efficiency 
of photosystem II (Fv/Fm). The method can be applied non-destructively, allowing for easy and fast assessment of the impact of various stress factors. For instance, it can be used to determine the susceptibility of tissues to various levels and types of illumination [47].

The survival of the F. excelsior is undoubtedly endangered by the influence of many environmental factors. For this reason, the degree of threat to the $F$. fraxineus population in Europe from individual biotic and abiotic factors should be assessed individually. In this study, we investigate the impact of three such factors: fungi commonly occurring in tissues of F. excelsior, heavy metals and various levels of salinity. In particular, our research was to: (i) determine the pathogenic potential of three fungi commonly occurring on F. excelsior, i.e., H. fraxineus, T. basicola, and Minimidochium sp., towards F. excelsior tissues in dual cultures, (ii), determine the influence of heavy metals (nickel, cadmium and lead) on different plant tissues (iii) determine the resistance of $F$. excelsior tissues to various concentrations of $\mathrm{NaCl}$.

The main aim of the present study was to investigate and determine the harmfulness of selected biotic and abiotic factors in in vitro culture of $F$. excelsior at a cellular level, excluding the negative influence of environmental factors.

The conducted laboratory tests constitute the basis for supporting and developing effective field experiments related to the protection of F. excelsior population in the forest environment.

\section{Materials and Methods}

\subsection{Source and Disinfection of Plant Material, Initiation of Plant Cultures In Vitro}

Seeds (ca. 900) of European ash were collected from 60-year-old trees growing in

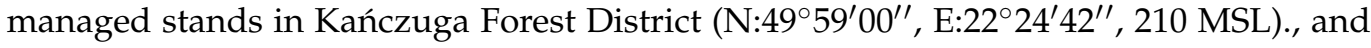
then stored in closed containers at $7{ }^{\circ} \mathrm{C} \pm 1{ }^{\circ} \mathrm{C}$ in the dark. Prior to culturing, the seeds were surface sterilized using the procedure described under patent application no. DP.P.433288, WO2021187995A2 involving two step disinfection with sodium hypochlorite. In addition, the procedure was supplemented with ultrasound treatment $(42 \mathrm{kHz})$ using an ultrasound generator (CHEMLAND, Stargard Szczeciński, Poland) to increase disinfection agent penetration into heavily contaminated seeds. The seeds were stored and subjected to further physiological and biotechnological tests in the laboratories of the Faculty of Forestry, Hugo Kołłataj University of Agriculture, Faculty of Biochemistry, Biophysics and Biotechnology, Jagiellonian University and Institute of Plant Physiology, Polish Academy of Sciences in Krakow.

The plant tissue cultures were initiated using zygotic embryos (primary explants) extracted from disinfected ash seeds by culturing them in Petri dishes on the MS medium (Murashige and Skoog 1962) [48] with modifications described in patent application DP.P.433288, WO2021187995A2. The method of obtaining common ash seedlings (Fraxinus excelsior L.) and substrates was suitable for this purpose. The cultures were incubated in a plant growth chamber (Biogent, Fito, Polska), at $23^{\circ} \mathrm{C} \pm 1{ }^{\circ} \mathrm{C}$ and $70 \%$ humidity, under white light $380-710 \mathrm{~nm}$, photoperiod $12 \mathrm{~h}$. The resulting callus cultures were used to regenerate primary seedlings that in turn were used to generate secondary seedlings (DP.P.433288, WO2021187995A2). All the downstream analyses used either callus cultures or seedlings of selected genotypes produced in this step. For tests involving fungal pathogens and endophytes and the impact of heavy metals we used the clones, either seedlings or callus cultures, of three genotypes. To investigate the impact of various concentrations of salt we used seedlings or callus cultures of four genotypes, except for the tests involving the measurements of catalase and peroxidase activity, at least three F. excelsior genotypes were used. All experiments included controls, results for which have been shown in the figures. A total of 264 tissue culture samples ( 210 callus samples and 54 seedling samples) along with controls were used in the experiments.

\subsection{Plant-Fungus Dual Cultures}

In this experiment we used F. excelsior callus cultures and seedlings, and cultures of three fungi: ash pathogen $H$. fraxineus (isolate 20952) and two ash endophytes: T. basicola 
(isolate C43) and Minimidochium sp. (isolate Jp49). Fungi species such as H. fraxineus and T. basicola were isolated from plant material collected from an area of southern Poland

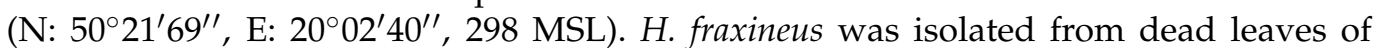
F. excelsior sludge collected in 2017 from litter. The endophyte T. basicola was isolated from the asymptomatic leaf petiole of F. excelsior. Minimidochium sp., came from live leaves of F. excelsior collected in the Kraków-Zakrzówek forest area (N: 50 02'22.62' , E: $19^{\circ} 54^{\prime} 57.60^{\prime \prime}$, 207 MSL). The selection of endophyte species was due to the fact that T. basicola and Minimidochium sp. out of 90 previously tested species in the Department of Endophytes showed the widest zone of inhibition and developed crystal-line forms in vitro [49]. The surface sterilization of fungi was performed according to the following procedure: the tails/shoots were disinfected by immersion in ethanol (96.00\%) for $1 \mathrm{~min}$, then in $\mathrm{NaOCl}$ solution (approximately $4 \%$ of available chlorine) for $5 \mathrm{~min}$ and in ethanol $(96.00 \%)$ for $30 \mathrm{~s}$. The samples were then dried by placing them on blotting paper [49]. The prepared fungi material was ready for the establishment of dual cultures. The dual cultures were prepared on modified MS medium for rhizogenesis (DP.P.433288, WO2021187995A2), either in Petri dishes for callus cultures or in crystallizing dishes for seedlings. Each time, a single callus piece or seedling was placed approximately $5 \mathrm{~mm}$ to the side of a dish and coupled with an agar plug (diam. $5 \mathrm{~mm}$ ) cut from actively growing fungal colony placed at the dish's center. Together with the controls, 24 samples (12 samples with callus tissue and 12 samples with seedlings) were used. Such prepared dual cultures were incubated for 21 days.

\subsection{The Impact of Selected Heavy Metals on Development of F. excelsior Callus Cultures and Seedlings}

Callus cultures and seedlings used in this experiment were preselected based on their overall physiological condition choosing only the best developed specimens. All the selected callus cultures, approximately $2 \mathrm{~cm}$ on average, were well-hydrated, characterized by compact cell structure, while the selected seedlings had correctly developed root and leaves. As before, callus cultures were transferred aseptically to Petri dishes and seedlings to crystallizing dishes filled with modified MS medium for rhizogenesis supplemented with various concentrations of heavy metals. The following combinations of media were prepared: no metal addition (negative control), $0.027 \mathrm{mmol} / \mathrm{L}$ of elemental Cd, $0.014 \mathrm{mmol} / \mathrm{L}$ of elemental $\mathrm{Pb}$ and $0.049 \mathrm{mmol} / \mathrm{L}$ of $\mathrm{Ni}$ in the form of nickel chloride hexahydrate $\left(\mathrm{NiCL}_{2}\right.$ $\times 6 \mathrm{H}_{2} \mathrm{O}$ ) (Merck KGaA, Darmstadt, Germany). Such prepared dishes were wrapped in parafilm and cultured in a plant growth chamber at $23{ }^{\circ} \mathrm{C} \pm 1{ }^{\circ} \mathrm{C}$ and humidity $70.00 \%$, and under white LED light 380-710 $\mathrm{nm}$ with a photoperiod of $12 \mathrm{~h}$. Together with the controls, 24 samples (12 samples with callus tissue and 12 samples with seedlings) were used. The experiment was run until all the callus cultures and seedlings died due to heavy metal exposure, that is, approximately 90 days.

\subsection{Protein Extraction and Antioxidative Enzymes Activities Assessment}

Soluble proteins were isolated from leaves $(0.1 \mathrm{~g}$ FW) homogenised in a cooled mortar in $2.5 \mathrm{~mL}$ of extraction buffer $\left(3 \mathrm{mM} \mathrm{MgSO}_{4}, 1 \mathrm{mM}\right.$ DTT, $3 \mathrm{mM}$ EDTA, $100 \mathrm{mM}$ Tricine $\mathrm{pH}$ 8.0, TRIS). The supernatant obtained after centrifugation $(20,000 \times g, 20 \mathrm{~min})$ was used to determine the activity of the antioxidant enzymes. Protein concentration was determined according to Bradford's method (1976) [50] with Bio-Rad Protein Assay (Bio-Rad, Hercules, CA, USA) and using bovine serum albumin (BSA) as a standard. CAT activity was assessed according to Aebi (1984) [51] monitoring the disappearance of $\mathrm{H}_{2} \mathrm{O}_{2}$ at $240 \mathrm{~nm}$ in $50 \mathrm{mM}$ phosphate buffer $\mathrm{pH}$ 7.0. Enzyme activity was determined in units (U) defined as $1 \mathrm{mmol}$ of $\mathrm{H}_{2} \mathrm{O}_{2}$ degraded in $1 \mathrm{~min}$ with $1 \mathrm{mg}$ of protein. Non-specific peroxidase (POX) activity was measured following $\mathrm{H}_{2} \mathrm{O}_{2}$-dependent p-phenylenediamine ( $\mathrm{pPD}$ ) decomposition for $2 \mathrm{~min}$ at $460 \mathrm{~nm}$. The extinction coefficient of $1.545 \times 103 \mathrm{M}^{-1} \mathrm{~cm}^{-1}$ was used according to Allgood and Perry (1985) [52]. Total non-specific peroxidase activity was described as nmol of pPD decomposed in $1 \mathrm{~min}$ with $1 \mathrm{mg}$ of protein. For biochemical analysis, the pooled samples obtained from at least three ash callus and seedlings cultivated at different $\mathrm{NaCl}$ 
concentration and in control conditions were used and two independent experiments were performed. All biochemical analyses were carried out at least, in three replicates. Overall, 108 tissue culture samples (93 callus samples and 15 seedling samples) were used in the experiment along with the controls.

\subsection{The Influence of Different Salinity Concentrations on the Physiology of Tissue Cultures} In Vitro

Analogically as before, the callus cultures and seedlings were preselected and transferred to either Petri dishes or crystallizing dishes filled with MS medium supplemented with various concentrations of $\mathrm{NaCl}$. The concentration combinations included: no $\mathrm{NaCl}$ addition (negative control) and $0.5 \%(85.5 \mathrm{mM}), 1.0 \%(171.0 \mathrm{mM})$ and $1.5 \%(256.5 \mathrm{mM})$ of $\mathrm{NaCl}$. The dishes were transferred to plant growth chamber and cultured for 30 days under the same conditions as described before. Next, the physiological condition of salt-exposed callus cultures and seedlings was evaluated based on the maximum quantum efficiency of the PSII parameter (Fv/Fm). Directly before measurements, the callus cultures and seedlings were kept in the dark for approximately $25 \mathrm{~min}$. The measurements were performed with an Open FluorCam FC 800-O fluorimeter (Photon Systems Instruments, Brno, Czech Republic) using saturating light pulse, intensity $2700 \mu \mathrm{E} \mathrm{m}^{-2} \mathrm{~s}^{-1}$ for $800 \mathrm{~ms}$ and $30 \mathrm{~s}$ illumination. Overall, 108 tissue culture samples (93 callus samples and 15 seedling samples) were used in the experiment along with the controls.

\subsection{Statistical Analyzes}

All the analyses were carried out using the $\mathrm{R}$ program for statistical analysis and graphics (R Core Team 2021). The analysis of variance (ANOVA) was performed with 'stats' package to compare the influence of metals and fungi growth on each type of plant material. To check which means were different, Tukey's post-hoc test was carried out using the 'agricolae' package. An ANOVA and Tukey's multiple post-hoc multiple range test were also performed to determine significant differences between callus and seedling of common ash and treatments with different $\mathrm{NaCl}$ concentrations, with significance set at $p<0.05$. Statistical tests including statistically significant differences as well as standard deviations are presented in Figures 1-7 and in Tables 1-6. The performed statistical analyses marked with different letters are statistically significant. The results contained in Tables 2, 3 and 6 have been additionally visualized in Figures 1-3 and 6 in order to better illustrate them.

\section{Results}

\subsection{The Impact of Biotic Stress Factors on the Callus Cultures and Seedlings of F. excelsior}

The results of analysis of variance (Table 1) showed that there are statistically significant differences in the mycelial growth of studied species of fungi toward F. excelsior tissues. However, the growth rates of both tissue types were similar. There were no interactions between the species of fungi and the type of plant material used (Table 1). 
Table 1. Analysis of variance for fungi growth towards and opposite the plant material. Df-degrees of freedom, Sum Sq—sum of squares, Mean Sq-mean square, F value -F statistic, $\operatorname{Pr}(>\mathrm{F})$ - $p$-value, ***-statistically significant results, Fungus-analysed fungi (Hymenocyphus fraxineus, Thielavia basicola, Minimidochium sp.); Plant material—type of plant material (non embryogenic callus tissue, seedling); Fungus $\times$ Plant material-interaction between fungus and plant material (Hymenocyphus fraxineus $\times$ seedling, Hymenocyphus fraxineus $\times$ non embryogenic callus tissue, Thielavia basicola $\times$ seedling, Thielavia basicola $\times$ non embryogenic callus tissue, Minimidochium $\times$ seedling, Minimidochium $\times$ non embryogenic callus tissue).

\begin{tabular}{|c|c|c|c|c|c|c|}
\hline Sources of Variance & Df & Sum Sq & Mean Sq & F Value & $\operatorname{Pr}(>\mathrm{F})$ & \\
\hline \multicolumn{7}{|c|}{ Fungus growth towards plant material (mm) } \\
\hline Fungus & 2 & 308.37 & 154.18 & 59.163 & $<0.001$ & $* * *$ \\
\hline Plant material & 1 & 0.00 & 0.00 & 0.001 & 0.976 & \\
\hline Fungus $\times$ Plant material & 2 & 18.96 & 9.48 & 3.638 & 0.061 & \\
\hline Residuals & 11 & 28.67 & 2.61 & & & \\
\hline \multicolumn{7}{|c|}{ Fungus growth opposite the plant material (mm) } \\
\hline Fungus & 2 & 276.91 & 138.45 & 71.390 & $<0.001$ & $* * *$ \\
\hline Plant material & 1 & 7.74 & 7.74 & 3.989 & 0.071 & \\
\hline Fungus $\times$ Plant material & 2 & 0.96 & 0.48 & 0.249 & 0.784 & \\
\hline Residuals & 11 & 21.33 & 1.94 & - & - & \\
\hline
\end{tabular}

Unsurprisingly, $H$. fraxineus showed the fastest mycelial growth, measured as colony radius, toward F. excelsior tissues reaching $24 \mathrm{~mm}$ for callus cultures and $23.70 \mathrm{~mm}$ for seedlings (Table 2). It also produced the largest overall colonies of $25 \mathrm{~mm}$ (Figure 2). T. basicola growth toward the ash tissues was slower and it varied between tissue types: $16.70 \mathrm{~mm}$ for callus and $19.30 \mathrm{~mm}$ (Table 2). Thus, the growth rate of T. basicola toward seedlings was not statistically different from the growth rate of $H$. fraxineus (Table 2). The Minimidochium sp. growth rate toward plant copartner was the slowest for both tissue types (Table 2, Figure 1). Similar mycelial growth rates to the plant copartner were observed for $H$. fraxineus and T. basicola (Table 1), but they were two times smaller compared to Minimidochium sp. whose average colony radius in this direction reached $17 \mathrm{~mm}$ and $16 \mathrm{~mm}$, respectively, for callus cultures and seedlings (Table 2, Figure 2).

Table 2. The Average fungal growth of the analyzed fungi. The same letters indicate the lack of statistically significant differences $(p<0.05)$, only the letters marked with the same number should be compared.

\begin{tabular}{|c|c|c|c|}
\hline Fungus & $\begin{array}{c}\text { Non-Embryonic Callus } \\
\text { Tissue }\end{array}$ & Seedling & Average \\
\hline \multicolumn{4}{|c|}{ Fungus growth towards plant material (mm) } \\
\hline Hymenocyphus fraxineus & 24.00 & 23.70 & $23.80(\mathrm{a})^{1}$ \\
\hline Thielavia basicola & 16.70 & 19.30 & $18.00(b)^{1}$ \\
\hline Minimidochium sp. & 14.30 & 12.00 & $13.17(\mathrm{c})^{1}$ \\
\hline Average & $17.76(\mathrm{a})^{2}$ & $18.30(\mathrm{a})^{2}$ & - \\
\hline \multicolumn{4}{|c|}{ Fungus growth opposite the plant material (mm) } \\
\hline Hymenocyphus fraxineus & 8.00 & 9.00 & $8.60(b)^{3}$ \\
\hline Thielavia basicola & 6.70 & 8.70 & $7.67(b)^{3}$ \\
\hline Minimidochium sp. & 16.00 & 17.00 & $16.50(a)^{3}$ \\
\hline Average & $10.50(\mathrm{a})^{4}$ & $11.55(\mathrm{a})^{4}$ & - \\
\hline
\end{tabular}



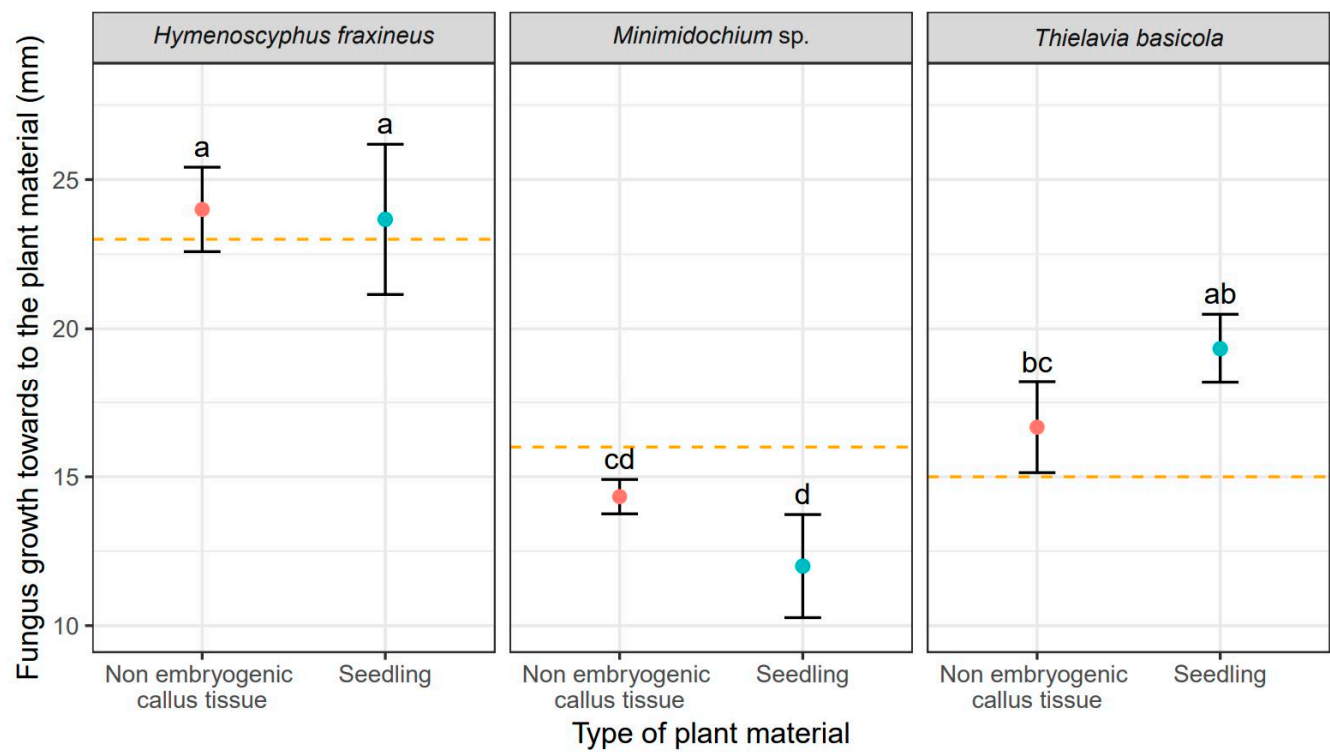

Figure 1. Mean values (points) and standard deviations (error bars) for fungus size in the direction towards to the plant material (red-non embryogenic callus tissue, light blue-seedling). The orange dashed lines show fungus size in the experiments without plant material. The same letters indicate the lack of statistically significant differences $(p<0.05)$.
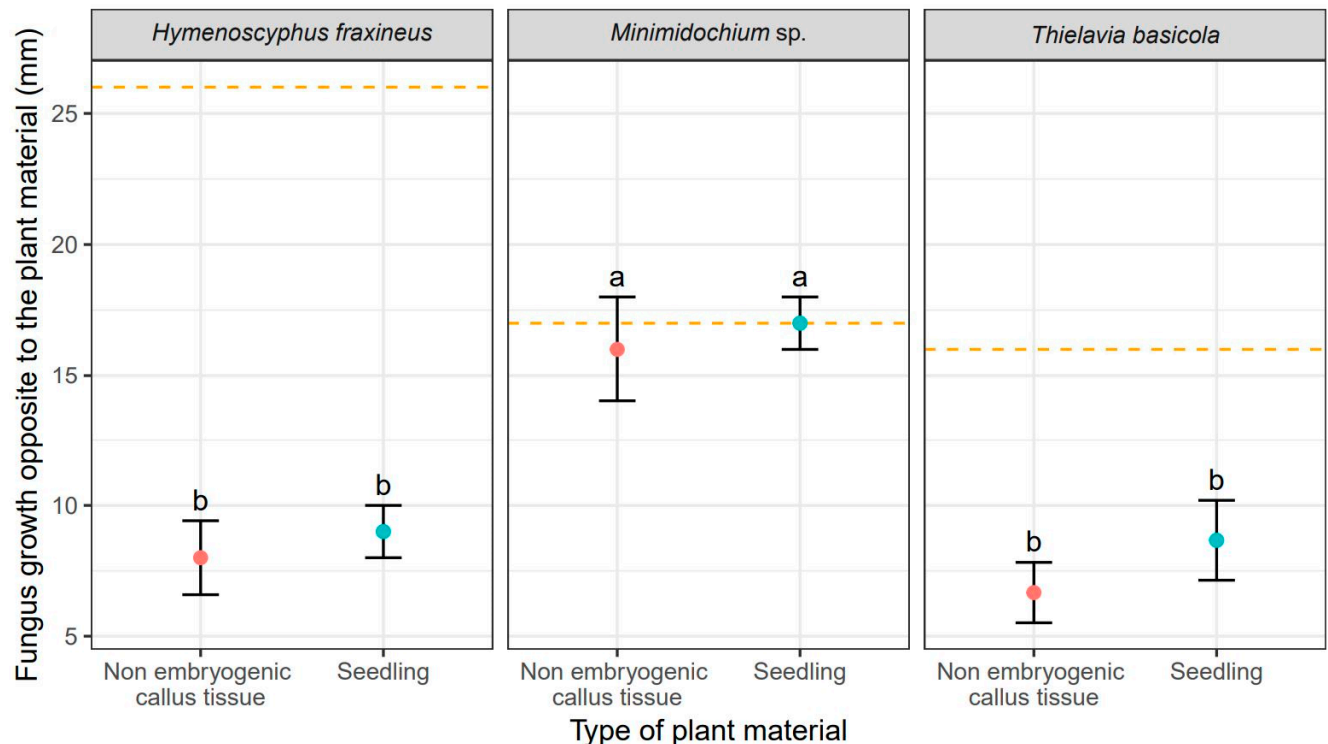

Figure 2. Mean values (points) and standard deviation s (error bars) for fungus size in the direction opposite to the plant material (red-non embryogenic callus tissue, light blue-seedling). The orange dashed lines show fungus size in the experiments without plant material. The same letters indicate the lack of statistically significant differences $(p<0.05)$.

The callus tissue exposed to the presence of all three fungi in dual cultures stopped developing morphogenetically upon contact with the copartners, but no browning or other readily noticeable signs of necroses were observed. The opposite was true for seedlings whose morphology was affected by fungi. Seedlings co-cultured with $H$. fraxineus curled up and turned brown, while Minimidochium sp. exposed seedlings wilted but mostly remained green, the browning occurred only on the leaves in the first whorl. Seedlings coupled with T. basicola, on the other hand, curled up in the similar way to those exposed to H. fraxineus but they turned brown only partially. All these symptoms, that is curling-up, wilting and browning of the tissues, indicate on-going dieback of the tissues. 


\subsection{The Impact of Abiotic Stress Factors on the Callus Cultures and Seedlings of F. excelsior}

\subsubsection{Heavy Metals}

Comparison of the effect of the tested heavy metals showed significant differences in the time required for a given metal to cause complete dieback of callus cultures and seedlings. These differences for particular genotypes are shown in Figure 3. Addition of cadmium resulted in the fastest dieback of plant tissues. For callus cultures, it was approximately 39 days, but the earliest signs of necroses were already visible on the 14th day of culturing. In seedlings, the complete dieback occurred after 62 days (Table 3). In comparison, the average time required for lead and nickel to completely kill plant tissues was 48 and 106 days, respectively for callus cultures, and 113 and 106 days, respectively for seedlings (Table 3). Thus, the effect of heavy metal addition on callus culture was similar for cadmium and lead resulting in their relatively quick dieback. However, the impact of lead on F. excelsior seedlings was weaker compared to cadmium, as the time necessary for this metal to kill seedlings was the longest. (Table 3, Figure 3). Moreover, the experiment showed that seedlings were less susceptible to the toxic effect of all three heavy metals compared to callus cultures (Table 3, Figure 3). The differences in the effect of heavy metal additions were statistically significant in analysis of variance (Table 4 ).
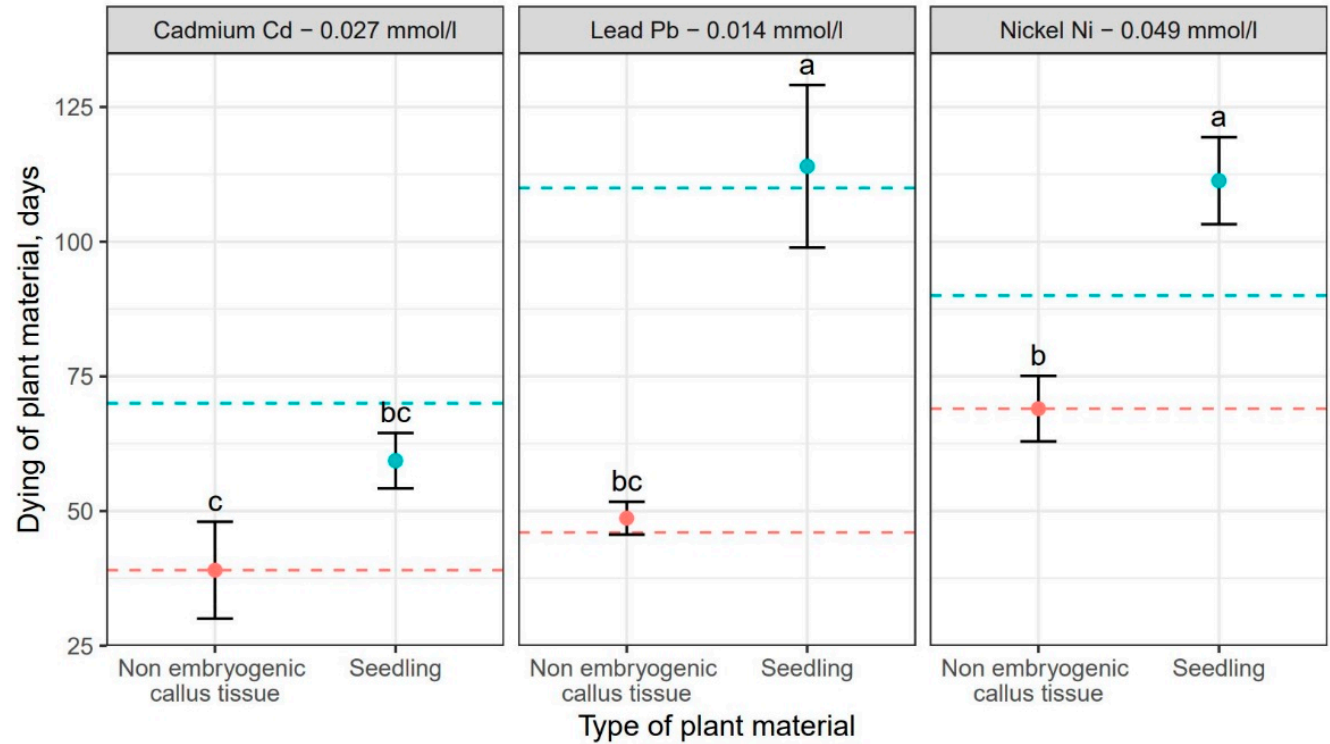

Figure 3. Mean values (points) and standard deviations (error bars) for dieback of plant material (red-non embryogenic callus tissue, light blue-seedlings) under the influence of selected heavy metals. The dashed lines show the development of plant material (red-non embryogenic callus tissue, light blue-seedlings) in experiments without the heavy metals. The same letters indicate the lack of statistically significant differences $(p<0.05)$.

Table 3. Average time required for heavy metal additions to cause complete dieback of $F$. excelsior seedlings and callus cultures. The same letters indicate lack of statistically significant differences $(p<0.05)$, only the letters marked with the same number should be compared.

\begin{tabular}{cccc}
\hline Metal & Non-Embryonic Callus Tissue & Seedling & Average \\
\hline & Dieback (days) & Dieback (days) & $87.5(\mathrm{a})^{1}$ \\
Nickel 0.049 & 69.00 & 106.00 & $80.5(\mathrm{a}){ }^{1}$ \\
Lead 0.014 & 48.00 & 113.00 & $50.5(\mathrm{~b})^{1}$ \\
Cadmium 0.027 & 39.00 & 62.00 & - \\
Avarge & $52.00(\mathrm{~b})^{2}$ & $93.70(\mathrm{a})^{2}$ & - \\
\hline
\end{tabular}


Table 4. Analysis of variance for plant material dying under the influence of metals. Df-degrees of freedom, Sum Sq-sum of squares, Mean Sq-mean square, F value $-\mathrm{F}$ statistic, $\operatorname{Pr}(>\mathrm{F})$ - $p$-value, ***-statistically significant results, Metal—analyzed heavy metals $(\mathrm{Ni}, \mathrm{Pb}, \mathrm{Cd})$; Metal $\times$ Plant materialinteraction between metal and plant material $(\mathrm{Ni} \times$ seedling, $\mathrm{Ni} \times$ non embryogenic callus tissue, $\mathrm{Pb} \times$ seedling, $\mathrm{Pb} \times$ non embryogenic callus tissue, $\mathrm{Cd} \times$ seedling, $\mathrm{Cd} \times$ non embryogenic callus tissue).

\begin{tabular}{|c|c|c|c|c|c|c|}
\hline Sources of Variance & Df & Sum Sq & Mean Sq & F Value & $\operatorname{Pr}(>F)$ & \\
\hline Metal & 2 & 6181.00 & 3091.00 & 41.58 & $<0.001$ & $* * *$ \\
\hline Plants material & 1 & $10,417.00$ & $10,417.00$ & 140.13 & $<0.001$ & $* * *$ \\
\hline Metal $\times$ Plant material & 2 & 1829.00 & 915.00 & 12.30 & $<0.001$ & $* * *$ \\
\hline Residuals & 18 & 1338.00 & 74.00 & - & - & \\
\hline
\end{tabular}

\subsubsection{Catalase and Peroxidase (POX) Activities}

The activity of antioxidant enzymes CAT and POX depended on both, the tissue type (callus vs. seedlings), as well as the $\mathrm{NaCl}$ concentration (Figures 4 and 5). We showed that the tolerance of ash callus and seedling tissues to salinity stress is linked to changes in antioxidant enzymes such as catalase and peroxidase that play a significant role in scavenging of $\mathrm{H}_{2} \mathrm{O}_{2}$ (Figures 4 and 5). Our result suggest that the constitutive activity level of CAT and POD in plant tissues play a key role in ash tissue tolerance to salinity. We found that in control samples of callus and seedlings, the direction of change in catalase and peroxidase activities was opposite; while, catalase activity was higher in callus tissues than in seedlings, in contrast POX activity was higher in seedlings when compared to callus tissue (Figures 4 and 5). The obtained results suggest that catalase plays a major role in the regulation of constitutive $\mathrm{H}_{2} \mathrm{O}_{2}$ in callus tissues, whereas POX in seedlings, and also suggest a differential constitutive oxidation-reduction status of these tissues which may be pivotal in the resistance to salt stress. In general, the activity of CAT was lower in NaCl-treated callus cultures compared to the control, among which the highest CAT activity was observed in $1 \% \mathrm{NaCl}$ concentration (Figure 4) whereas for seedlings, the $\mathrm{NaCl}$ concentration of $0.5 \%$ stimulated CAT activity compared to the control, but concentrations of 1.0 and $1.5 \%$ had an opposite effect. The overall activity of non-specific peroxidases (POX) in callus tissue exposed to $0.5 \% \mathrm{NaCl}$ was similar to this in the control, but in callus cultures exposed to $1.0 \%$ and $1.5 \%$ concentrations it was significantly lower (Figure 5). Concentration of $1.0 \%$ increased POX activity in seedling tissues compared to the control, whereas at $0.5 \%$ and $1.5 \%$ concentrations of $\mathrm{NaCl}$ the activity of POX was decreased.

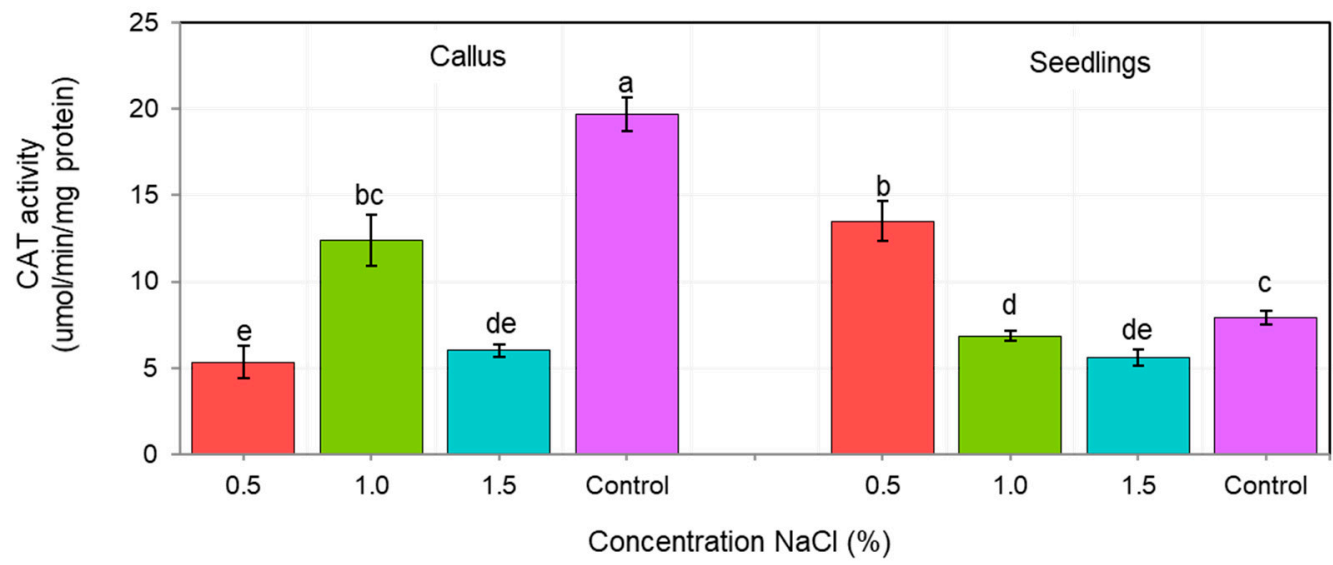

Figure 4. Changes in catalase activity (CAT) in callus and seedlings of F. excelsior L. Other lettersthere are statistically significant differences. 


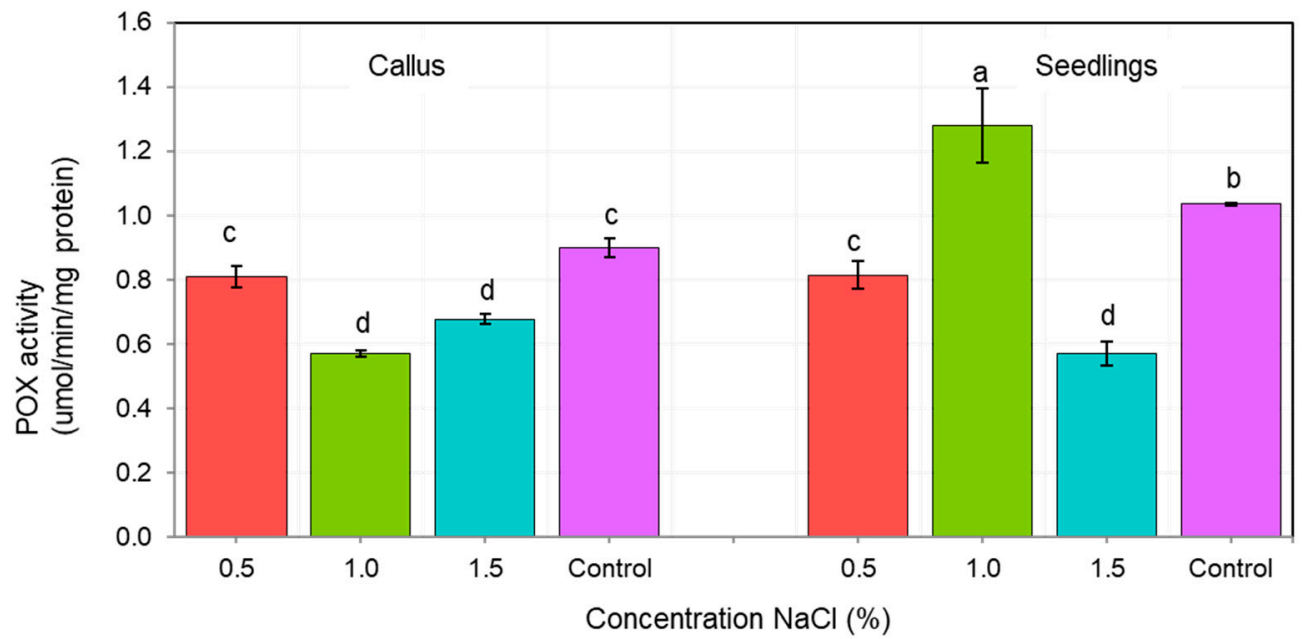

Figure 5. Changes in nonspecific peroxidase (POX) activity in of F. excelsior callus and seedlings. Other letters-there are statistically significant differences.

\subsubsection{Salinity}

Subsequently, the impact of salinity stress was evaluated based on the effectiveness of the light-dependent phase of photosynthesis. The analysis of variance did not show any statistically significant differences between the individual genotypes and the salinity concentration (Table 5). Unsurprisingly, the highest maximum quantum effectiveness of PSII for callus tissue was recorded for the control cultures (no $\mathrm{NaCl}$ addition), with no statistically significant differences among the genotypes (Table 6, Figure 6). Among the $\mathrm{NaCl}$-treated callus cultures, the lowest Fv/Fm was recorded for genotype G3 (Table 6), but these values were not statistically different from those observed in genotypes G1 and G3. These genotypes (G1 and G2) did not differ statistically form G4 (Tables 5 and 6), whose Fv/Fm was the highest among NaCl-treated callus cultures (Table 6, Figure 6). Nonetheless, the Fv/Fm values for callus cultures, including the control, were always lower than those recorded for seedlings, among which no statistically significant differences were observed, including differences among the genotypes and all $\mathrm{NaCl}$ concentrations. For all the experimental combinations in seedlings the Fv/Fm values ranged from 0.79 to 0.85 .

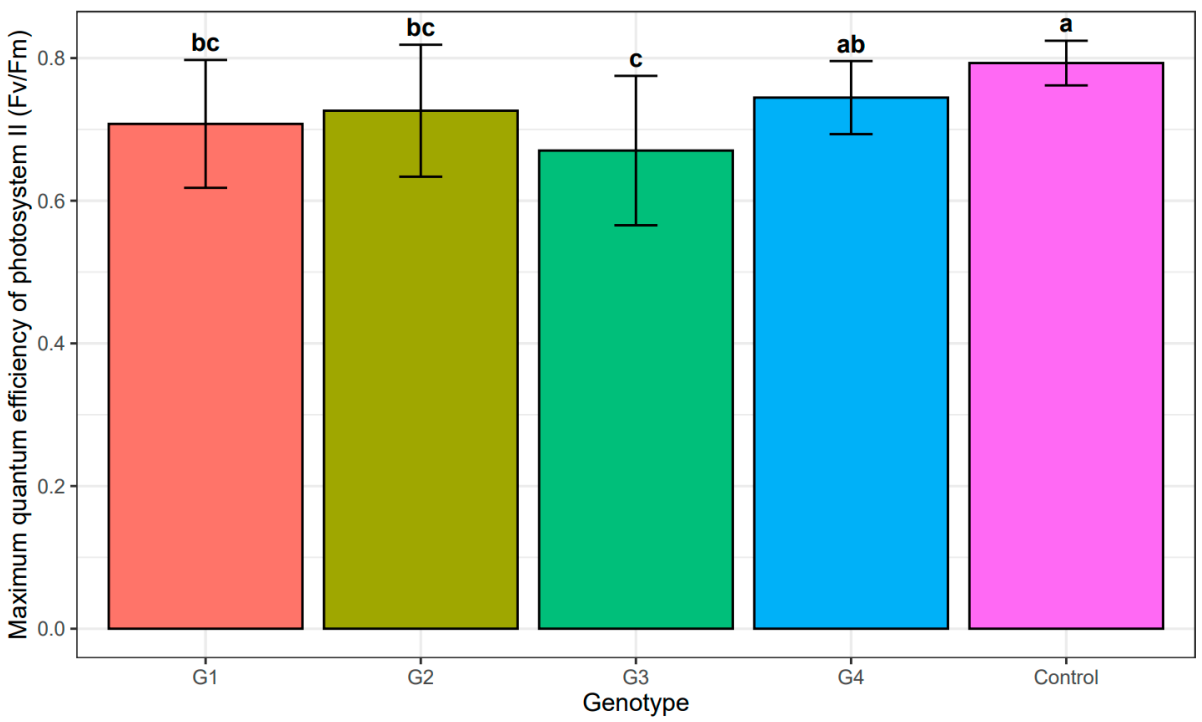

Figure 6. Mean value and standard deviation of maximum quantum efficiency of photosystem II (Fv/Fm) of individual genotypes: G1-G4 under the influence of salinity and control. The same letters indicate lack of statistically significant differences $(p<0.05)$. 
Table 5. Analysis of the variance of genotypes: G1-G4 under the influence of salinity and control. Df-degrees of freedom, Sum Sq-sum of squares, Mean Sq-mean square, F value - F statistic, $\mathrm{Pr}$ $(>\mathrm{F})-p$-value.

\begin{tabular}{cccccc}
\hline Sources of Variance & Df & Sum Sq & Mean Sq & F Value & Pr $(>$ F) \\
\hline \multicolumn{5}{c}{ All studied genotypes and control } \\
\hline Genotype & 4 & 0.1434 & 0.0358 & 6.308 & $<0.001$ \\
Residuals & 88 & 0.5001 & 0.0057 & & \\
\hline \multicolumn{5}{c}{ Genotype G1 } \\
\hline Concentration & 2 & 0.0805 & 0.0402 & 25.1885 & $<0.001$ \\
Residuals & 10 & 0.0160 & 0.0016 & \\
\hline \multicolumn{7}{c}{ Genotype G2 } \\
\hline Concentration & 2 & 0.0165 & 0.0082 & 0.402 \\
Residuals & 18 & 0.1546 & 0.0086 & \\
\hline & Genotype G3 & & \\
\hline Concentration & 2 & 0.0166 & 0.0083 & \\
Residuals & 12 & 0.1369 & 0.0114 & \\
\hline & Genotype G4 & & \\
\hline Concentration & 2 & 0.0151 & 0.7277 & \\
Residuals & 21 & 0.0453 & 0.0022 & \\
\hline
\end{tabular}

Table 6. Results and statistics of maximum quantum efficiency of photosystem II (Fv/Fm) values for the genotypes: G1-G4 under the influence of salinity, concentration of $\mathrm{NaCl}: 0.5,1.0,1.5$ (\%), and control. Value-mean value for genotype; SD—standard deviation; $\mathrm{n}$-number of callus examples; Min-minimum value; Max-maximum value; Q25, Q50, Q75-quantiles; groups-Tukey HSD groups (groups with the same letter are not statistically different $p<0.5$, only the letters marked with the same number should be compared).

\begin{tabular}{|c|c|c|c|c|c|c|c|c|c|c|}
\hline & $\begin{array}{c}\text { Concentration } \\
\mathrm{NaCl}\end{array}$ & Value & SD & $\mathbf{n}$ & Min & $\operatorname{Max}$ & Q25 & Q50 & Q75 & Groups \\
\hline & \multicolumn{10}{|c|}{ Genotype G1 } \\
\hline & 0.5 & 0.77 & 0.02 & 7 & 0.74 & 0.80 & 0.75 & 0.76 & 0.78 & $\mathrm{a}^{1}$ \\
\hline & 1.0 & 0.71 & 0.04 & 3 & 0.67 & 0.75 & 0.69 & 0.71 & 0.73 & $a^{1}$ \\
\hline & 1.5 & 0.57 & 0.07 & 3 & 0.50 & 0.64 & 0.53 & 0.57 & 0.60 & $b^{1}$ \\
\hline \multirow[t]{5}{*}{ G1 Total } & & 0.71 & 0.09 & 13 & 0.50 & 0.80 & 0.67 & 0.75 & 0.76 & $\mathrm{bc}^{2}$ \\
\hline & \multicolumn{10}{|c|}{ Genotype G2 } \\
\hline & 0.5 & 0.76 & 0.01 & 7 & 0.73 & 0.77 & 0.76 & 0.76 & 0.76 & $a^{3}$ \\
\hline & 1.0 & 0.68 & 0.17 & 5 & 0.41 & 0.82 & 0.61 & 0.76 & 0.81 & $a^{3}$ \\
\hline & 1.5 & 0.73 & 0.06 & 9 & 0.60 & 0.80 & 0.68 & 0.74 & 0.78 & $a^{3}$ \\
\hline \multirow[t]{5}{*}{ G2 Total } & & 0.73 & 0.09 & 21 & 0.41 & 0.82 & 0.72 & 0.76 & 0.77 & $b c^{2}$ \\
\hline & \multicolumn{10}{|c|}{ Genotype G3 } \\
\hline & 0.5 & 0.72 & 0.03 & 3 & 0.69 & 0.75 & 0.70 & 0.71 & 0.73 & $\mathrm{a}^{4}$ \\
\hline & 1.0 & 0.64 & 0.11 & 9 & 0.41 & 0.76 & 0.63 & 0.68 & 0.71 & $\mathrm{a}^{4}$ \\
\hline & 1.5 & 0.70 & 0.12 & 3 & 0.58 & 0.83 & 0.64 & 0.70 & 0.77 & $a^{4}$ \\
\hline \multirow[t]{5}{*}{ G3 Total } & & 0.67 & 0.10 & 15 & 0.41 & 0.83 & 0.64 & 0.70 & 0.72 & $c^{2}$ \\
\hline & \multicolumn{10}{|c|}{ Genotype G4 } \\
\hline & 0.5 & 0.77 & 0.03 & 12 & 0.73 & 0.81 & 0.74 & 0.78 & 0.79 & $a^{5}$ \\
\hline & 1.0 & 0.72 & 0.07 & 8 & 0.61 & 0.80 & 0.69 & 0.73 & 0.78 & $a^{5}$ \\
\hline & 1.5 & 0.71 & 0.04 & 4 & 0.67 & 0.76 & 0.69 & 0.70 & 0.72 & $a^{5}$ \\
\hline G4 Total & & 0.74 & 0.05 & 24 & 0.61 & 0.81 & 0.71 & 0.75 & 0.79 & $a b^{2}$ \\
\hline Control & & 0.79 & 0.03 & 20 & 0.72 & 0.83 & 0.78 & 0.80 & 0.82 & $a^{2}$ \\
\hline
\end{tabular}

However, at the concentration of $1.5 \% \mathrm{NaCl}$, the sample for the $\mathrm{G} 1$ genotype genotype differed statistically significantly from the other samples in a different range of salinity 
concentrations (Table 6, Figure 7). However, the remaining replications (G2, G3 and G4 genotypes) were not significant at selected salinity concentrations (Table 6, Figure 7).
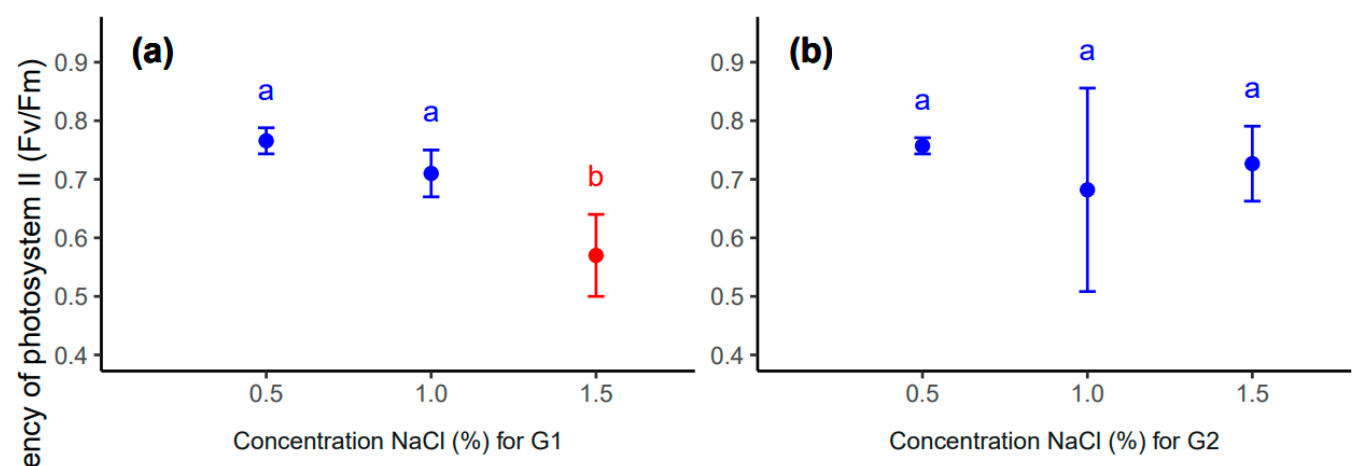

(c)

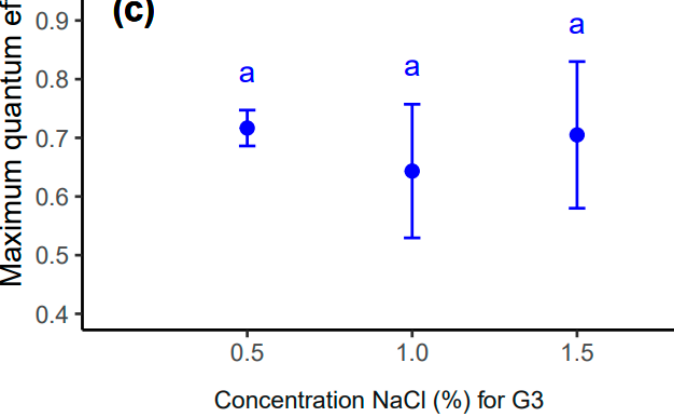

(d)

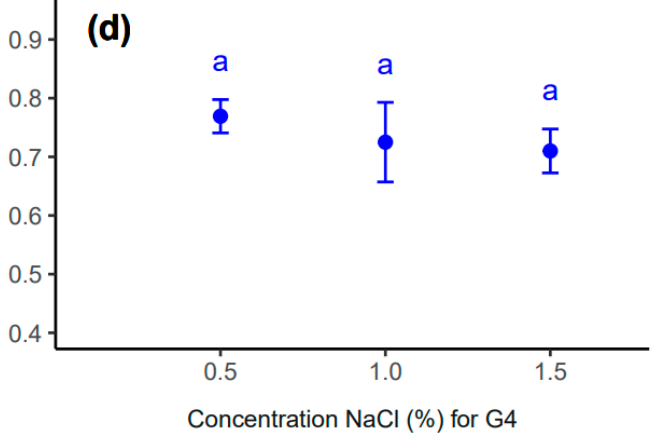

Figure 7. Mean value (point) and standard deviation (error bar) for genotype: G1 (a), G2 (b), G3 (c) and G4 (d) in different concentrations of $\mathrm{NaCl}$ : 0.5, 1.0, 1.5 (\%). The same letters inside each subplot indicate the lack of statistically significant differences between means $(p<0.05)$.

\section{Discussion}

European ash is a species with a profound ecological impact, whose presence regulates the amount of light reaching the lower parts of the stand shaping the species composition and biodiversity of underbrush and groundcover communities. Its organic debris in the litter stimulates cycling of elements in forest ecosystems [53]. However recently, the condition of F. excelsior in Europe is weak due to a variety of biotic and abiotic environmental factors among which the most prominent is ash dieback caused by $H$. fraxineus. For many European countries, the weakening of the F. excelsior population is so pronounced that it threatens the very existence of the species. For these reasons, we conducted a series of in vitro experiments aiming to evaluate the susceptibility of selected genotypes of F. excelsior to various environmental stress factors. Initially, the procedure involved plant tissue cultures used to produce the test material comprising callus cultures and seedlings regenerated via indirect organogenesis. This kind of method has a great potential for use in forest sciences in a number of practical applications. As an example, the indirect somatic organogenesis was successfully used to evaluate the regenerative potential of Aleppo pine (Pinus halepensis Mill.), as well as to select genotypes based on their susceptibility to environmental factors [54].

A modification of standard plant tissue cultures are plant-fungus dual cultures. The method is particularly useful to evaluate the pathogenicity of various fungal species to their host without need for extensive field experiments, as it allows the disease process to be approximated in a controlled environment. Numerous studies using this technique helped to assess the course and impact of fungal diseases in trees [55]. Therefore, we used a dual culture approach to evaluate the relative pathogenicity of two ash endophytes, T. basicola and Minimidochium sp. and an ash pathogen $H$. fraxineus. Their pathogenicity to F. excelsior tissues (measured as growth rate toward the plant copartner), varied significantly (Tables 1 and 2). $H$. fraxineus and T. basicola colonized both tissue types, callus and seedlings, in a similar manner. 
The growth pattern of Minimidochium sp. was different, as its colonies preferred to grow away from the plant tissues (Figure 2). The conducted experiment showed that selected species of endophytes have a completely different effect on callus and common ash seedlings. The results showed that the T. basicola endophyte poses a threat to the health and development of the common ash as well as the potent pathogen $H$. fraxineus. Therefore, it is desirable to carry out further experiments with the use of endophyte species, the effect of which on common ash tissue may cause plant death. These studies can be additionally supplemented by the genetic analysis of representatives F. excelsior with the use of very precise analysis of genomic estimated breeding values (GEBVs). The GEBVs method is a very precise and accurate analysis that allows determination of the susceptibility of individuals to fungal infections. The application of the (GEBVs) method may complement the in vitro tests of European ash tissue culture, the final result of which will be the selection of tree genotypes resistant to fungal infections [11].

The impact of heavy metal pollution is another issue examined in this study. We compared the impact of three heavy metals on F. excelsior callus cultures and seedlings. It turned out that the effects of cadmium and lead differed to that of nickel (Table 4). The first two metals caused quick dieback of callus cultures, but the time necessary to kill seedlings was much longer (Table 3, Figure 3). For nickel, the time necessary to kill callus cultures and seedlings was very similar. The results of the research show that tissue cultures of F. excelsior react differently to changing concentrations of heavy metals in the substrate. On the basis of the research results, it is advisable to use F. excelsior as a biomonitor to assess the actual state of environmental pollution in urbanized areas [32]. It is desirable to conduct laboratory research at a cellular level on the basis of which it will be possible to determine the degree of damage to the plant tissues taken from the urban environment. These studies will enable the precise determination of environmental pollution with heavy metals and allow the search for an F. excelsior genotype resistant to industrial pollution. Taking this into account, one should focus on finding a solution that would minimize the negative impact of heavy metals on F. excelsior. On the basis of the tests carried out, which showed the negative effect of heavy metals on the seedlings and callus of common ash, attention should be paid to the environmental factors that will limit the accumulation of heavy metals by plants. An important factor reducing the availability of heavy metal in the soil is the amount organic matter in the forest floor. This is because, many organic compounds form complexes with heavy metal ions that are not easily absorbed by plants. Numerous analyses show the significant role of deciduous trees in this process due to the large amounts of organic debris produced each year with cast leaves. In predominantly deciduous forest stands the soil condition is improved by increased $\mathrm{pH}$ and by accumulation of heavy metals by organic matter. Importantly, the absorption of heavy metals by trees may be significantly reduced by various management strategies and recultivation treatments. Recent analyses show that negative impact of heavy metals on various physiological processes, especially those related to photosynthesis and respiration, may be mitigated by salicylic acid (SA) treatment [56-58]. Therefore, our studies on the susceptibility of F. excelsior tissues to heavy metals should be expanded, including other metals (zinc, chromium, copper [59], but also to evaluate the mitigating effect of phytohormones. This kind of result may help to develop growth regulator treatments effective in reducing the heavy metal stress in F. excelsior and in other plants.

The last stress factor examined in our study was salinity, which was analyzed using two parameters, that is, activity of antioxidant enzymes and maximum quantum efficiency of PSII. The former analysis involved measurements of CAT and POX which was either increased or decreased, compared to the control, depending on the concentration of $\mathrm{NaCl}$ and on the tissue type (callus vs. seedlings). In callus cultures, $\mathrm{NaCl}$ concentrations of $1.0 \%$ and $1.5 \%$ inhibited the activity of both enzymes (Figures 4 and 5) whereas, in seedlings the activity of CAT or POX was stimulated by $\mathrm{NaCl}$ addition in concentrations of $0.5 \%$ and $1.0 \%$ (Figures 4 and 5). Higher concentrations of $\mathrm{NaCl}(1.5 \%)$ appear to be toxic, even for seedlings. This suggests that moderate levels of salinity stress increase 
the amounts of ROS being released in tissues, which in turn triggers antioxidant defense response in seedlings. The same reaction was not observed for callus cultures. Here, the addition of salt caused reduction in activity of CAT and POX enzymes suggesting the callus tissue is characterized by lower defense potential against salinity stress compared to seedlings. We showed that both seedlings and callus of ash are able to develop during slight/medium (not exceeding $0.5 \%$ or $1.0 \%$ ) salt stress. Our results are in agreement with Raddi et al. [60] who showed that F. angustifolia (Vahl.) is able to germinate at low salinity and to tolerate temporarily moderate salinity (not exceeding $75 \mathrm{mM} \mathrm{NaCl}$ ) conditions. Interestingly, the activity of CAT and POX enzymes in the control, both in callus and seedlings, varied significantly. This indicates that both enzymes play a role in organogenesis and morphogenetic differentiation of callus tissue and suggests that a certain threshold level of $\mathrm{H}_{2} \mathrm{O}_{2}$, (different for callus tissue and for seedlings) is necessary for the proper functioning of these processes. Catalase is a commonly used peroxisomal marker and plays a key role in removal of photorespiratory $\mathrm{H}_{2} \mathrm{O}_{2}$ [61]. However, it may also reflect the activity of other peroxisomal metabolic pathways, especially those related to nitrogen metabolism, fatty acid oxidation and phytohormone biosynthesis (e.g., indolyl-3-acetic acid (IAA) and jasmonic acid (JA)) [61,62]. As a result of environmental changes, corner plants are under stress causing changes in their morphology, biochemistry and philosophy. Plants exposed to environmental stress such as drought produce excessive amounts of ROS in their cells. The reactive forms of telnus lead to damage to and death of plant cells and entire tissues. In order to prevent cell damage by ROS under conditions of high environmental stress, plants have evolved processes to prevent damage under stress. Plants produce substances such as sugars (fructose, sucrose), sugar alcohols (mannitol) and amino acids (proline), which act as antioxidants under stress conditions. These substances support the detoxification of ROS, support the protection of membranes and improve the stability of enzymes and proteins. Ultimately, the plant becomes resistant to abiotic factors $[63,64]$. Under environmental stress, photorespiration acts as an energy sink, preventing excessive reduction of the photosynthetic electron transport chain and photoinhibition, as well as preventing the accumulation of $\operatorname{ROS}[60,65]$. Peroxidases in general are involved in multiple metabolic processes during the entire life cycle of plants, including the metabolism of ROS, reactive nitrogen species (RNS) and metabolism of phytohormones (e.g., auxins), as well as in the production of lignin and suberin, and in cross-linking of cell wall components [41, 42,66]. We can conclude that through regulation of $\mathrm{ROS} / \mathrm{H}_{2} \mathrm{O}_{2}$ levels, CAT and POX are involved in specific signalling pathways [42] including those involved in salt stress tolerance. In previous studies the differentiation in antioxidant enzyme activities has been shown to be linked with salt tolerance as well as morphogenic processes, organogenesis [43], rhizogenesis [44], totipotency potential and plant (oak) development [67].

Maximum quantum effectiveness of PSII (Fv/Fm) was another parameter used to evaluate the level of salinity stress experienced by F. excelsior tissues. The measurements showed that the Fv/Fm values recorded for callus cultures were always lower than those observed in seedlings, regardless of the $\mathrm{NaCl}$ concentration. This is, presumably, due to differences in the maturity of photosynthetic apparatus between these two types of plant material. Photosynthetic machinery in totipotent callus cells is expected to be less developed and less efficient compared to seedling leaves, where cells are organized to efficiently utilize light energy and to minimize damage caused by its excess [68]. When examining the Fv/Fm values for a salt-treated callus, differences in the amount of damage caused by $\mathrm{NaCl}$ stress became visible (Table 6). The most stable photosynthetic apparatus under these conditions was recorded for genotype G4, while the apparatus of the G3 genotype turned to be the weakest. Similar differences were not observed in seedlings, for which Fv/Fm values recorded under salinity stress did not differ statistically either among the $\mathrm{NaCl}$ concentrations, including the control, or the genotypes. Presumably, the proper development and maturity of the photosynthetic apparatus, on structural and molecular levels, is a much stronger factor determining the quantum effectiveness of PSII, under examined $\mathrm{NaCl}$ concentrations, than differences between the genotypes. 
There is no doubt that the methods presented in the article as well as the results of our analyses can serve as useful basis for their application in functional research aiming to protect $F$. excelsior stands against negative effects of environmental factors. This is mostly due to the use of in vitro techniques for both production of larger amounts of plant material and for actual testing at cellular level and for plants in their youngest stages of development, i.e., seedlings. Such methods may potentially greatly facilitate testing of the effects of various biotic and abiotic environmental factors, as well as selection of resistant genotypes. Routine use of micropropagation techniques to produce F. excelsior seedlings, coupled with in vitro selection for increased resistance, may be a valid reason to reevaluate the current restrictions on planting of European ash in forests.

\section{Conclusions}

Our experiments indicate that the analyzed factors, i.e., the examined species of fungi, heavy metals and $\mathrm{NaCl}$ concentrations, affect the growth and development of European ash under controlled conditions. The results obtained allowed us to draw the following conclusions: $H$. fraxineus undoubtedly has the features of a strong pathogen. Ash endophytes co-cultured with F. excelsior callus cultures or seedlings gradually damage the plant copartner resulting in its dieback and overgrowth. Ash endophytes, such as T. basicola, may act in the similar manner as pathogens. Despite the lack of any adverse environmental factors, T. basicola caused $14.37 \%$ (callus) and $37.82 \%$ (seedlings) faster dieback of ash tissues than Minimidochium sp. The pathogenic potential of T. basicola is indicated in the literature, as the species may be a cause of brown root rot in many plant species. The statistical analyses and standard deviations performed showed that there are significant differences in the development of mushroom cultures towards tissue cultures. Heavy metals negatively affect the growth and development of F. excelsior tissue cultures, ultimately causing their gradual dieback. The statistical analyses and standard deviations showed that there are significant differences between the time of callus tissue death and the seedlings. The most harmful effect among the studied metals was observed for cadmium, whose concentration of $0.027 \mathrm{mmol} / \mathrm{L}$ was toxic to ash tissue cultures. $F$. excelsior seedlings produced in vitro were, in general, less susceptible to heavy metals than callus. Acquired results indicate that morphogenetic development of F. excelsior callus tissue is accompanied by the variable activity of antioxidant enzymes (CAT and POX) controlling the level of $\mathrm{H}_{2} \mathrm{O}_{2}$. This suggests that $\mathrm{H}_{2} \mathrm{O}_{2}$ may play a role in cell signaling regulating organogenesis/development of seedlings in European ash. Due to the less differentiated intensity of chlorophyll fluorescence in the tested material, the sensitivity of the method was higher for callus measurements $(95.00 \%)$ than for seedlings (50.00\%). The callus genotype $\mathrm{G} 1$ at $1.5 \% \mathrm{NaCl}$ salinity showed visible inhibition. No significant differences were observed among studied genotypes in the susceptibility to heavy metals and to fungal infections.

\section{Patents}

Nawrot-Chorabik, K.; Latowski, D. 2020. Polish Patent No. DP.P.433288. Sposób pozyskiwania sadzonek jesionu wyniosłego (Fraxinus excelsior L.) oraz pożywki nadajace się do stosowania w tym sposobie. Method of obtaining common ash seedlings (Fraxinus excelsior L.) and substrates suitable for this method https:/ / ewyszukiwarka.pue. uprp.gov.pl/search/pwp-details/P.433288?lng=pl. Accessed on 20 September 2021.

Worldwide Patent No. WO2021187995A2. The method of obtaining saplings of the common ash (Fraxinius excelsior L.) and the media suitable for use in this method https: / / worldwide.espacenet.com/patent/search/family/075954228/publication/WO202118799 5A2?q=PCT\%2FPL2021\%2F050017. Accessed on 23 September 2021.

Author Contributions: Conceptualization, K.N.-C.; methodology, K.N.-C., M.O., E.S. and D.L.; software, V.M., E.S.; validation, K.N.-C., M.O., E.S. and D.L.; formal analysis, K.N.-C., M.S., M.O., V.M., E.S. and D.L.; investigation, K.N.-C.; writing-original draft preparation, K.N.-C.; writing- 
review and editing, K.N.-C.; visualization, M.S., M.O., V.M., E.S. and D.L.; supervision, K.N.-C.; funding acquisition, M.S. All authors have read and agreed to the published version of the manuscript.

Funding: This research was funded by the Ministry of Education and Science in Poland, topic number SUB/040013-D019.

Institutional Review Board Statement: Not applicable.

Informed Consent Statement: Not applicable.

Data Availability Statement: Department of Forest Ecosystems Protection, Faculty of Forestry, University of Agriculture in Krakow, https:/ / wl.urk.edu.pl/ (accessed on 1 December 2021); Faculty of Biochemistry, Biophysics and Biotechnology of the Jagiellonian University, https:/ / wbbib.uj.edu. pl/ (accessed on 1 December 2021); Institute of Plant Physiology of the Polish Academy of Sciences, http:/ /ifr-pan.krakow.pl/ (accessed on 1 December 2021).

Acknowledgments: The co-authors thank Tadeusz Kowalski for providing fungal isolates.

Conflicts of Interest: The authors declare no conflict of interest.

\section{References}

1. Heuertz, M.; Carnevale, S.; Fineschi, S.; Sebastiani, F.; Hausman, J.F.; Paule, L.; Vendramin, G.G. Chloroplast DNA phylogeography of European ashes, Fraxinus sp. (Oleaceae): Roles of hybridization and life history traits. Mol. Ecol. 2006, 15, 2131-2140. [CrossRef] [PubMed]

2. Musolin, D.L.; Selikhovkin, A.V.; Shabunin, D.A.; Zviagintsev, V.B.; Baranchiko, Y.B. Between ash dieback and emerald ash borer: Two asian invaders in Russia and the future of ash in Europe. Balt. For. 2017, 23, 316-333.

3. Keča, N.; Tkaczyk, M.; Żółciak, A.; Stocki, M.; Kalaji, H.M.; Nowakowska, J.A.; Oszako, T. Survival of European ash seedlings treated with phosphite after infection with the Hymenoscyphus fraxineus and Phytophthora species. Forests 2018, 9, 442. [CrossRef]

4. Dobrowolska, D.; Hein, S.; Oosterbaan, A.; Wagner, S.; Clark, J.; Skovsgaard, J.P. A review of European ash (Fraxinus excelsior L.): Implications for silviculture. Forestry 2011, 84, 133-148. [CrossRef]

5. Fijołek, M. Atlas Dzikich Roślin Jadalnych (Atlas of Wild Edible Plants), 1st ed.; Wydawnictwo SBM: Warsaw, Poland, 2017; pp. 66-67.

6. Farrell, E.P.; Führer, E.; Ryan, D.; Andersson, F.; Hüttl, R.; Piussi, P. European forest ecosystems: Building the future on the legacy of the past. For. Ecol. Manag. 2000, 132, 5-20. [CrossRef]

7. Surówka, E.; Rapacz, M.; Janowiak, F. Climate change influences the interactive effects of simultaneous impact of abiotic and biotic stresses on plants. In Plant Ecophysiology and Adaptation under Climate Change: Mechanisms and Perspectives I; Hasanuzzaman, M., Ed.; Springer: Singapore, 2020; pp. 1-50.

8. Kowalski, T.; Bilański, P. Fungi detected in the previous year's leaf petioles of fraxinus excelsior and their antagonistic potential against Hymenoscyphus fraxineus. Forests 2021, 12, 1412. [CrossRef]

9. Turczański, K.; Rutkowski, P.; Dyderski, M.K.; Wrońska-Pilarek, D.; Nowiński, M. Soil pH and organic matter content affects European ash (Fraxinus excelsior L.) crown defoliation and its impact on understory vegetation. Forests 2020, 11, 22. [CrossRef]

10. Lenz, H.D.; Bartha, B.; Straßer, L.; Lemme, H. Development of ash dieback in south-eastern Germany and the increasing occurrence of secondary pathogens. Forests 2016, 7, 41. [CrossRef]

11. Stocks, J.J.; Metheringham, C.L.; Plumb, W.J.; Lee, S.J.; Kelly, L.J.; Nichols, R.A.; Buggs, R.J.A. Genomic basis of European ash tree resistance to ash dieback fungus. Nat. Ecol. Evol. 2019, 3, 1686-1696. [CrossRef]

12. Fones, H.N.; Mardon, C.; Gurr, J.G. A role for the asexual spores in infection of fraxinus excelsior by the ash-dieback fungus Hymenoscyphus fraxineus. Sci. Rep. 2016, 6, 1-10.

13. Gross, A.; Sieber, T.N. Virulence of Hymenoscyphus albidus and native and introduced Hymenoscyphus fraxineus on Fraxinus excelsior and Fraxinus pennsylvanica. Plant Pathol. 2016, 65, 655-663. [CrossRef]

14. Kowalski, T.; Holdenrieder, O. The teleomorph of Chalara fraxinea, the causal agent of ash dieback. For. Pathol. 2009, 39, 304-308. [CrossRef]

15. Bakys, R.; Vasaitis, R.; Skovsgaard, J.P. Patterns and severity of crown dieback in young even-aged stands of european ash (Fraxinus excelsior L.) in relation to stand density, bud flushing phenotype, and season. Plant. Prot. Sci. 2013, 49, 120-126. [CrossRef]

16. Han, J.-G.; Shrestha, B.; Hosoya, T.; Lee, K.-H.; Sung, G.-H.; Shin, H.-D. First report of the ash dieback pathogen Hymensocyphus fraxineus in Korea. Mycobiology 2014, 42, 391-396. [CrossRef] [PubMed]

17. Enderle, R.; Metzler, B.; Riemer, U.; Gerald, K. Ash dieback on sample points of the national forest inventory in south-western Germany. Forests 2018, 9, 25. [CrossRef]

18. Ioos, R.; Kowalski, T.; Husson, C.; Holdenrieder, O. Rapid in planta detection of Chalara fraxinea by a real-time PCR assay using a dual-labelled probe. Eur. J. Plant Pathol. 2009, 125, 329-335. [CrossRef]

19. Ustawa o Lasach. 1997, Dz. U. 1991 Nr 101 poz. 444 (The Act on Forests. 1997. NS. of Laws 1991 No. 101, item 444). Available online: https:/ / isap.sejm.gov.pl/isap.nsf/DocDetails.xsp?id=WDU19911010444 (accessed on 1 December 2021). 
20. Nawrot-Chorabik, K.; Marcol-Rumak, N.; Latowski, D. Investigation of biocontrol potential of two ash endophytes against Hymenoscyphus fraxineus using in vitro plant-fungus dual cultures. Forests 2021, 12, 1750. [CrossRef]

21. Bálint, M.; Tiffin, P.; Hallström, B.; O’Hara, R.B.; Olson, M.S.; Fankhauser, J.D.; Piepenbring, M.; Schmitt, I. Host genotype shapes the foliar fungal microbiome of balsam poplar (Populus balsamifera). PLoS ONE 2013, 8, e53987. [CrossRef] [PubMed]

22. Nawrot-Chorabik, K. Interactions between embryogenic callus of Abies alba and Heterobasidion spp. in dual cultures. Biol. Plant. 2014, 58, 363-369. [CrossRef]

23. Hrib, J.; Rypacek, V. A simple callus test to determine the aggressiveness of wood-destroying fungi. Eur. J. For. Pathol. 1981, 11, 270-274. [CrossRef]

24. Nawrot-Chorabik, K.; Pietrzykowski, M. Ecophysiological aspects of in vitro biotechnological studies using somatic embryogenesis of callus tissue toward protecting forest ecosystems. J. For. Res. 2019, 30, 1159-1166. [CrossRef]

25. Bhusal, N.; Lee, M.; Reum Han, A.; Han, A.; Kim, H.S. Responses to drought stress in Prunus sargentii and Larix kaempferi seedlings using morphological and physiological parameters. For. Ecol. Manag. 2020, 465, 118099. [CrossRef]

26. Tseng, S.; Liang, C.; Chia, T.; Ton, S. Changes in the composition of the soil bacterial community in heavy metal-contaminated farmland. Int. J. Environ. Res. Public Health 2021, 18, 8661. [CrossRef] [PubMed]

27. Caracciolo, A.B.; Terenzi, V. Rhizosphere microbial communities and heavy metals. Microorganisms 2021, 9, 1462. [CrossRef] [PubMed]

28. Naveed, M.; Bukhari, S.S.; Mustafa, A.; Ditta, A.; Alamri, S.; El-Esawi, M.A.; Rafique, M.; Ashraf, H.; Siddiqui, N.H. Mitigation of nickel toxicity and growth promotion in sesame through the application of a bacterial endophyte and zeolite in nickel contaminated soil. Int. J. Environ. Res. Public Health 2020, 17, 8859. [CrossRef]

29. Bashir, M.A.; Naveed, M.; Ashraf, S.; Mustafa, A.; Ali, Q.; Rafique, M.; Alamri, S.; Siddiqui, M.H. Performance of Zea mays L. cultivars in tannery polluted soils: Management of chromium phytotoxicity through theapplication of biochar and compost. Physiol. Plant. 2021, 173, 129-147. [CrossRef] [PubMed]

30. Niekerk, L.A.; Carelse, M.F.; Bakare, O.O.; Mavumengwana, V.; Keyster, M.; Gokul, A. The relationship between cadmium toxicity and the modulation of epigenetic traits in plants. Int. J. Mol. Sci. 2021, 22, 7046. [CrossRef]

31. Nas, F.S.; Ali, M. The effect of lead on plants in terms of growing and biochemical parameters. MOJ Ecol. Environ. Sci. 2018, 3, 265-268.

32. Severoglu, Z. Use of biomonitor European ash (Fraxinus excelsior L.) tree for monitoring traffic related heavy metal pollution in bishkek/kyrgyzstan: Impacts on plant nutrition. Fresenius Environ. Bull. 2018, 27, 9662-9673.

33. Chuifan, Z.; Huang, M.; Ren, H.; Yu, Y.; Wu, J.; Ma, X. Bioaccumulation and detoxification mechanisms for lead uptake identified in Rhus chinensis Mill. Seedlings. Ecotoxicol. Environ. Saf. 2017, 142, 59-68.

34. Narayani, M.; Srivastava, S. Elicitation: A stimulation of stress in in vitro plant cell/tissue cultures for enhancement of secondary metabolite production. Phytochem. Rev. 2017, 16, 1227-1252. [CrossRef]

35. Gorji, T.; Yildirim, A.; Sertel, E.; Tanik, A. Remote sensing approaches and mapping methods for monitoring soil salinity under different climate regimes. Int. J. Geoinform. 2019, 6, 33-49. [CrossRef]

36. Foyer, C.H.; Ruban, A.V.; Noctor, G. Viewing oxidative stress through the lens of oxidative signalling rather than damage. Biochem. J. 2017, 474, 877-883. [CrossRef]

37. Isayenkov, S.V.; Maathuis, F.J.M. Plant salinity stress: Many unanswered questions remain. Front. Plant Sci. 2019, 10, 80. [CrossRef] [PubMed]

38. Hussain, B.; Lucas, S.J.; Ozturk, L.; Budak, H. Mapping QTLs conferring salt tolerance and micronutrient concentrations at seedling stage in wheat. Sci. Rep. 2017, 7, 15662. [CrossRef]

39. Smirnoff, N.; Arnaud, D. Hydrogen peroxide metabolism and functions in plants. New Phytol. 2019, 221, 1197-1214. [CrossRef] [PubMed]

40. Das, K.; Roychoudhury, A. Reactive oxygen species (ROS) and response of antioxidants as ROS-scavengers during environmental stress in plants. Front. Environ. Sci. 2014, 2, 1-13. [CrossRef]

41. Munns, R.; Gilliham, M. Salinity tolerance of crops-What is the cost? New Phytol. 2015, 208, 668-673. [CrossRef] [PubMed]

42. Dumanović, J.; Nepovimova, E.; Natić, M.; Kuča, K.; Jaćević, V. The significance of reactive oxygen species and antioxidant defense system in plants: A concise overview. Front. Plant Sci. 2021, 11, 552969. [CrossRef] [PubMed]

43. Libik, M.; Konieczny, R.; Pater, B.; Ślesak, I.; Miszalski, Z. Differences in the activities of some antioxidant enzymes and in $\mathrm{H}_{2} \mathrm{O}_{2}$ content during rhizogenesis and somatic embryogenesis in callus cultures of the ice plant. Plant Cell Rep. 2005, 23, 834-841. [CrossRef]

44. Konieczny, R.; Banaś, A.K.; Surówka, E.; Michalec, Ż.; Miszalski, Z.; Libik-Konieczny, M. Pattern of antioxidant enzyme activities and hydrogen peroxide content during developmental stages of rhizogenesis from hypocotyl explants of Mesembryanthemum crystallinum L. Plant Cell Rep. 2014, 33, 165-177. [CrossRef] [PubMed]

45. Meratan, A.A.; Ghaffari, S.M.; Niknam, V. In vitro organogenesis and antioxidant enzymes activity in Acanthophyllum sordidum. Biol. Plant. 2009, 53, 5-10. [CrossRef]

46. Vatankhah, E.; Niknam, V.; Ebrahimzadeh, H. Activity of antioxidant enzyme during in vitro organogenesis in Crocus sativus. Biol. Plant. 2010, 3, 509-514. [CrossRef] 
47. Nawrot-Chorabik, K.; Osmenda, M.; Słowiński, K.; Latowski, D.; Tabor, S.; Woodward, S. Stratification, scarification and application of phytohormones promote dormancy breaking and germination of pelleted scots pine (Pinus sylvestris L.) seeds. Forests 2021, 12, 621. [CrossRef]

48. Murashige, T.; Skoog, F. A revised medium for rapid growth and bioassays with tobacco tissue cultures. Physiol. Plant. 1962, 15, 495-497. [CrossRef]

49. Kowalski, T.; Bilański, P. Hymenoscyphus pusillus, a new species on leaves of Fraxinus pennsylvanica in Poland. For. Pathol. 2019, 49, e12481.

50. Bradford, M.M. A rapid and sensitive method for the quantitationof microgram quantities of protein utilizing the principle ofprotein-dye binding. Anal. Biochem. 1976, 72, 248-254. [CrossRef]

51. Aebi, H. Catalase in vitro. In Methods in Enzymology; Academic Press: London, UK, 1984; Volume 105, pp. 121-126.

52. Allgood, G.S.; Perry, J.J. Oxygen defense systems in obligately thermophilic bacteria. Can. J. Microbiol. 1985, 31, 1006-1010. [CrossRef]

53. Erfmeier, A.; Haldan, K.L.; Beckmann, L.M.; Behrens, M.; Rotert, J.; Schrautzer, J. Ash dieback and its impact in near-natural forest remnants-A plant community-based inventory. Front. Plant Sci. 2019, 10, 658. [CrossRef]

54. Pereira, C.; Montalbán, I.A.; Pedrosa, A.; Tavares, J.; Pestryakov, A.; Bogdanchikova, N.; Canhoto, J.; Moncaleán, P. Regeneration of Pinus halepensis (Mill.) through organogenesis from apical shoot buds. Forests 2021, 12, 363. [CrossRef]

55. Fenning, T.M. The use of tissue culture and in-vitro approaches for the study of tree diseases. Tissue Organ Cult. 2019, 136, 415-430. [CrossRef]

56. Miura, K.; Tada, Y. Regulation of water, salinity, and cold stress responses by salicylic acid. Front. Plant Sci. 2014, 5, 1-12. [CrossRef]

57. Wang, Y.; Hu, J.; Qin, G.; Cui, H.; Wang, Q. Salicylic acid analogues with biological activity may induce chilling tolerance of maize (Zea mays) seeds. Botany 2012, 90, 845-855. [CrossRef]

58. Zengin, F. Effects of exogenous salicylic acid on growth characteristics and bio-chemical content of wheat seeds under arsenic stress. J. Environ. Biol. 2015, 36, 249

59. Hattori, H. Influence of heavy metals on soil microbial activities. Soil. Sci Plant Nut. 1992, 38, 93-100. [CrossRef]

60. Raddi, S.; Mariotti, B.; Martini, S.; Pierguidi, A. Salinity tolerance in Fraxinus angustifolia vahl.: Seed emergence in field and germination trials. Forests 2019, 10, 940. [CrossRef]

61. Corpas, F.J.; del Rio, L.A.; Palma, J.M. Plant peroxisomes at the crossroad of $\mathrm{NO}$ and $\mathrm{H}_{2} \mathrm{O}_{2}$ metabolism. J. Integr. Plant Biol. 2019, 61, 803-816

62. Mur, L.A.J.; Mandon, J.; Persijn, S.; Cristescu, S.M.; Moshkov, I.E.; Novikova, G.V.; Hall, M.A.; Harren, F.J.M.; Hebelstrup, K.H.; Gupta, K.J. Nitric oxide in plants: An assessment of the current state of knowledge. AoB Plants 2013, 5, 1-17. [CrossRef]

63. Bhusal, N.; Lee, M.; Lee, H.; Adhikari, A.; Han, A.R.; Kim, H.S. Evaluation of morphological, physiological, and biochemical traits for assessing drought resistance in eleven tree species. Sci. Total. Environ. 2021, 779, 146466. [CrossRef]

64. Khaleghi, A.; Naderi, R.; Brunetti, C.; Maserti, B.E.; Babalar, M. Morphological, physiochemical and antioxidant responses of Maclura pomifera to drought stress. Sci. Rep. 2019, 9, 19250. [CrossRef]

65. Bauwe, H.; Hagemann, M.; Kern, R.; Timm, S. Photorespiration has a dual origin and manifold links to central metabolism. Curr Opin. Plant Biol. 2012, 15, 269-275. [CrossRef]

66. Pandey, V.P.; Awasthi, M.; Singh, S.; Tiwari, S.; Dwivedi, U.N. A Comprehensive review on function and application of plant peroxidases. Biochem. Anal. Biochem. 2017, 6, 1. [CrossRef]

67. Racchi, M.; Bagnoli, F.; Balla, I.; Danti, S. Differential activity of catalase and superoxide dismutase in seedlings and in vitro micropropagated oak (Quercus robur L.). Plant Cell Rep. 2001, 20, 169-174.

68. Rousseau, C.; Belin, E.; Bove, E.; Rousseau, D.; Fabre, F.; Berruyer, R.; Guillaumes, J.; Manceau, C.; Jacques, M.-A.; Boureau, T. High throughput quantitative phenotyping of plant resistance using chlorophyll fluorescence image analysis. Plant Methods 2013, 17, 1-13. [CrossRef] 